\title{
An Empirical Study about Influence of China's Shadow Banking on the Stability of the Financial System
}

\author{
Bo Liu ${ }^{1}$, Shuai Shao ${ }^{1} \&$ Yan-yang $\mathrm{Gao}^{2}$ \\ ${ }^{1}$ Finance Department of International Business School, Jinan University, Zhuhai, China \\ ${ }^{2}$ Packaging Engineering Institute, Jinan University, Zhuhai, China \\ Correspondence: Shuai Shao, Finance Department of International Business School, Jinan University, Qianshan \\ Road 206\#, Zhuhai City, Guangdong Province, Post No. 519070, China. Tel: 86-137-5006-9121. E-mail: \\ 615914616@qq.com
}

Received: January 28, 2016

Accepted: February 19, 2016

Online Published: March 25, 2016

doi:10.5539/ijef.v8n4p104

URL: http://dx.doi.org/10.5539/ijef.v8n4p104

\begin{abstract}
With the rapid development of the financial system in recent years, all kinds of financial derivatives teem and the size of the shadow banking is becoming more and bigger. It has become an important factor affecting the stability of China's financial system. The influence of shadow banks on the financial system has two sides, on the one hand it is advantageous to the development and expansion of small and medium-sized enterprises as lubricant of corporate financing, on the other hand, features of shadow banking that highly leveraged and term mismatch also bring uncertainty to China's financial system. Firstly, this paper calculates the size of the shadow banking in China, and then builds a fuzzy comprehensive evaluation system to evaluate the risk of China's financial system. When determining the evaluation index, this paper apply KMV model to calculate the credit risk of China's securities market, and the maximum entropy method to determine the index weight. After getting China's financial system risk index and the size of shadow banking, this paper constructs the VAR model and makes the parameter estimation and impulse response analysis. Analysis results show that in a certain degree, the increase of the scale of shadow banks can reduce the risk of the financial system, but if it is over some certain threshold, it will increase the overall risk of the financial system.
\end{abstract}

Keywords: shadow banking, KMV model, fuzzy comprehensive evaluation, maximum entropy method, VAR model

\section{Introduction}

In recent decades, researches concerning the stability of the financial system emerge endlessly. Initially, scholars home and abroad started their researches on the stability of the financial system from a macro level. Fisher proposed the "debt-deflation theory" in 1933, thinking that the stability of the banking system is closely related to the macro economic cycle and changes in economic fundamentals is the root of changes in the stability of the banking system. And we concern the stability of the banking system from the macro economic cycle, the real interest rate, consumption increase rate, GDP, etc. However, the study did not stop there; then, scholars have realized there are a lot of connections between micro and macro, so they use a variety of mathematical model to make a series of analysis of micro data.

Since the 21st century, due to the rapid expansion of credit scale and the spread of financial derivatives and the off-balance sheet business, people pay more attention to the impact of the shadow banking on financial system. Financial crisis in 2008 makes researchers aware of the existence of the huge impact that the shadow banking bring to the financial system as well as the risks that of highly leveraged, and it makes the scholars no longer research only on macroscopic and microscopic angles, but on a new perspective which is shadow banking and improve and innovate continuously. For example, Gary B. Gorton and Andrew Metrick studied the connotation and relationship of "investors' confidence" and "liquidity" under the framework of financial crisis in 2007-2009, they think, due to the impact of the shadow banking system, the profitability of the traditional commercial bank's business gradually decline, as well as the on-balance sheet items (Gary B. Gorton \& Andrew Metrick, 2009). In 2012, Financial Survey and Statistics Department of People's Bank of China and the same department of Chengdu sub-branch see shadow banking as a useful supplement of formal financial institutions which strengthens the service function of financial markets on the one hand, and on the other hand also makes the 
liquidity of financial markets enhanced (Gary B. Gorton \& Andrew Metrick, 2012). The shadow banking operation will improve the profitability of commercial banks. There is not a same definition of shadow banks home and abroad, so the research direction begins to be different. It tends to study the effect of shadow banks on the financial system and the spread mechanism of financial instability overseas, while at home, we tend to study the positive and negative influence of shadow banking and the risks.

Overviewing on the development of shadow banking and the stability of financial system, we decide to summarize the experiences of our predecessors, analyze the effect of the scale of the shadow banking on the stability of the financial system based on the existing certain data. From the perspective of credit risk management, traditional credit risk prediction methods mainly include Z-score model proposed by an American scholar (Edward, 1968) and the credit risk prediction model using Logistic regression analysis whose assumptions are looser (Ohlson, 1980). But these two methods predict the future according to the past; they are too dependent on financial statement data. And with the development of credit risk management, credit risk management methods also have a big progress, including Credit Metrics, which is mainly used to quantify the risk management and KMV model set up by KMV Company in San Francisco established which is used to estimate the probability of borrowing enterprise default (Morgan's, 1997). Due to the measurement index of KMV model to the enterprise credit risk are mainly from analysis of data in stock market price changing, and the price of the stock market includes the investors information to determine stock in the future, therefore, KMV model is proactive and sensitivity, and more objective and accurate.

In recent years, the study of KMV model in our country has made a lot of progresses in the empirical analysis. Wei Lu, Hengyan Zhao and Jiyun Liu calculated volatility of company's assets and value of stock right using the data from China's stock market in the research Company Value Assessment in the application of KMV Model (Wei, Hengyan, \& Jiyun, 2003). They also build the relationship between them. Dong-ping Chen and Ming Sun proposed the function of loan defective rate and default distance in the research Modification and Application of KMV Model (Dong-ping \& Ming, 2007). Cheng Liu and Chen Zhang thought the KMV model has certain applicability to commercial banks in our country, but it must be modified in several aspects including determination of default point, market pricing of non-tradable shares, risk-free interest rate and lack of the default data in "Credit Risk Measurement Model and Parameter Correction in our country commercial banks based on the theory of option pricing" (Cheng \& Chen, 2011).

Executive director of the Pacific investment supervision company firstly put forward the concept of shadow banking; he defined the shadow banking as the financial structure corresponding to regular management of the banking system (McCulley, 2007). There is a research concerning under new financial system, the rise of shadow banking system is caused by competition, and under the background of relaxation of financial regulation, non-bank financial institutions has made significant development, facing the impact of non-banking institutions and their products, traditional banking profitability decline. From the balance sheet of commercial banks, we can see the assets are mainly commercial paper and junk bonds; debtor is mainly money market mutual funds (MMMF), and businesses in the table are less able to generate profits. Facing the profitability downward pressure, commercial banks actively seek new profit points to promote the emergence and development of the shadow banking system (Gorton \& Metrick, 2010). Because traditional insurance business does not involve business mortgage bonds, there is no systemic risk, but if credit derivatives products and other non-traditional business are involved, namely the shadow banking is involved, and there will be systemic risk. If under the strict risk management methods in assets, systemic risk can also be controlled (Bell \& Keller, 2009). Calmes and Theoret (2011) analyzed the shadow banking from the angle of off-balance-sheet assets, thought that traditional regulation methods should control off-balance-sheet assets risk from the source. The new Basel III is a great progress, but its effectiveness yet to be tested. Yue Liu in Central South University of Forestry and Technology described definition and characteristics of shadow banking, as well as the development of the shadow banking in our country, expounds potential risk of shadow banking and its impact to financial system in our country, and put forward corresponding preventive advices on this basis (Yue, 2015). In China, shadow banking mainly covers two pieces: one is financial products, and sales of various non-banking financial institutions in the type of credit products, such as trust company sales of products, which were sold passionately by commercial banks. Another is folk financial system on behalf of folk usury.

\section{Measurement of the Shadow Banking Scale and Construction of Financial System Stability Index}

\subsection{Measurement of the Shadow Banking Scale}

In 2007, the concept of Shadow Banking proposed by executive director Paul McCulley in Pacific Investment Management Company for the first time. Shadow Banking plays a similar function in the financial market as the 
traditional commercial banks and it provides functions of time to expiration, credit and liquidity conversion for individuals and small enterprise. Because of the characteristics including high leverage, term mismatch and opacity of shadow banking, its scale has always been a concern for regulators. And the definition of shadow banking is vague; the documents provide different diameter size measurement, so the overall sizes of shadow banking we get are also very different. For the convenience of calculation, the shadow banking system is divided into five parts: pawn shops, Internet finance, private lending, trust assets and bank financial products. They are respectively from Wind database, China Trustee Association, People's Bank of China and China Banking Regulatory Commission. As shown in Tab.1 in the appendix.

\subsection{The Composition of Financial System Stability Index}

International Monetary Fund (IMF) once built a global financial system stability index in 2006, including 12 core indexes and 27 encouraged indicators. This gives us a reference standard, for China, banking system accounts for a large proportion in the financial system, and non-bank financial institutions is closely related to the banking system, so when we are considering the stability of the banking system, we should focus on the stability of the financial system. We use financial stability theory and measurement method home and abroad for reference, summarize commonly used indicators, and then consider introducing some new indicators to establish comprehensive indicators in judging the stability of financial in China. This article selects three types, 12 indicators to determine the stability of the financial system in China: economic stability, financial stability and market risk indicators.

Economic stability indexes include GDP growth rate, inflation rate, and growth rate of investment on fixed assets and the ratio of fiscal deficit to GDP. GDP growth rate is an important indicator to measure stability of banking system; it can reflect a country's economic development condition most directly. Inflation rate is macroeconomic vulnerability index, reflecting a country's currency stability. Growth rate of investment on fixed assets which is obtained by the banking industry represents the higher the proportion of a country's infrastructure deficit to GDP growth rate is, the higher the country's fiscal deficit is. Investors lose confidence on the government's ability to guarantee the stability of the future sustainable economic development; it also has an impact on the banking system stability.

Financial stability indicators include M2 growth rate, household savings growth rate, financial institutions credit growth rate and the one-year deposit real rate.M2 growth rate reflects the increase or decrease speed of a country's currency supply, which has a direct impact on the bank's capital system. Household savings growth rate reflects the urban and rural residents' confidence to the stability of banking system to a certain extent. Financial institutions credit growth refers to the ratio of all kinds of loan balance annual growth of financial institutions to GDP growth previous year; it reflects changes of social financing scale and is an important aspect to measure the stability of the banking system. The one-year deposit interest rate reflects the social financing level and its cost, which is an important financial reference variable.

Market risk index mainly refers to the risk that internal banking system indicates. It consists of bank capital adequacy ratio, non-performing loan ratio, return ratio on assets and default distance in securities market. Bank capital adequacy ratio is the capital principal rate that financial institutions operate and develop necessarily, and it is used to measure the banking system risk. Non-performing loan ratio reflects the quality of bank loans and is also very important for the banking system stability. Return ratio on assets is used to measure the profitability of the banking sector, which is closely related to the financial system stability. Default rate plays an important role in the bank credit risk management, and is an indispensable index. It is calculated by KMV model.

\subsection{The Calculation of Default Rate in Securities Industry - The Calculation of KMV Model}

KMV model is also known as Expected Default rate of Firms Model (EDF model). Its principle is seeing corporate debt as a European call option, its executive price is corporate debt value and its object is underlying assets market value for the company. When enterprise's external liabilities due, and if the value of enterprise assets market is higher than its debt, the enterprise will repay debt. Otherwise, the enterprise will choose to default. The specific calculation steps of KMV model are as follows:

(1) According to the financial statements and the stock price data of listed companies, we use B-S model to get the market value of the company's assets and its stock price volatility. As equation 1 and 2:

$$
\begin{aligned}
& f_{s}=V_{A} N\left(d_{1}\right)-B e^{-r t} N\left(d_{2}\right) \\
& d_{1}=\frac{\operatorname{In}\left(\frac{V_{A}}{B}\right)+\left(r+\frac{\delta_{A^{2}}}{2}\right) T}{\delta_{A} \sqrt{T}} \quad d_{2}=d_{1}-\delta_{A} \sqrt{T}
\end{aligned}
$$


(2) We construct a default distance DD and default point DPT to evaluate the credit risk of listed companies. Default point DPT can be constructed through the proportion of current liabilities and non-current liabilities, $D P T=C L+0.5^{*} L L$, and CL stands for current liabilities, LL stands for non-current liabilities. Default distance DD refers to the distance from company's assets value to the default point (DPT). The greater the DD is, the smaller the possibility of corporate debt repayment crisis would happen, otherwise the opposite. As equation 3 ,

$$
D D=\frac{E\left(V_{A}\right)-D P T}{E\left(V_{A}\right) * \delta_{A} \sqrt{T}}
$$

(3) Building the expected default rates of enterprises (EDF) performs the probability of default corporate vividly. In this paper, we use the normal distribution function to simulate the default debts of enterprises. As equation 4,

$$
E D F=N(-D D)=1-\mathrm{N}(\mathrm{DD})
$$

In order to compare the changing in default distance of different period, different industries and different performance of listed companies, which is to reflect the credit risk of commercial banks better, we search for national commercial bank loan balances (grouped by industry), select 5 industries whose commercial banks loan balance are most in 2007-2014, and pick out 13 listed companies in these industries. As a comparison, we select leading stocks and risk stocks in these 5 industries, and obtain their credit risk according to their earnings and stock price data. The distribution of credit default probability is shown in Figure 1.

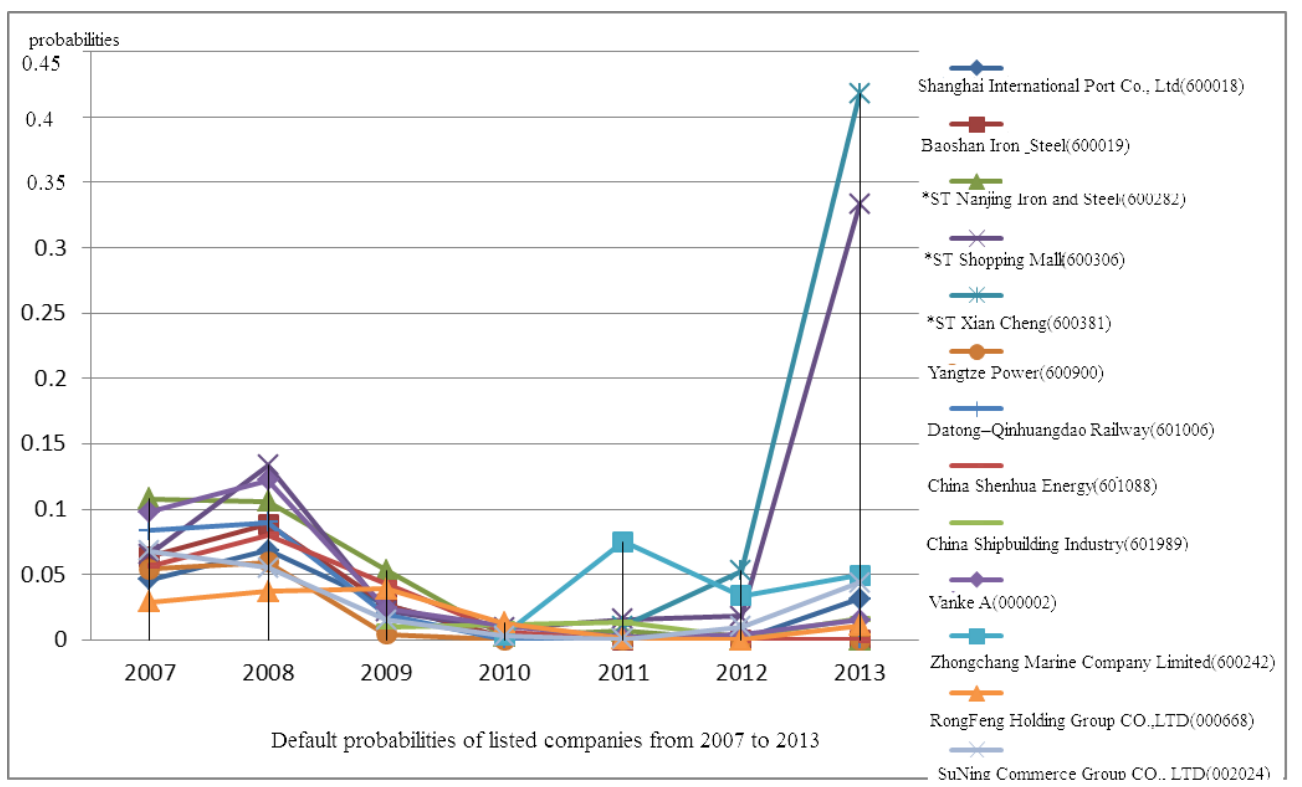

Figure 1. Credit default probability calculated by KMV model

We can get the value of default rate in securities market using according to credit default distance and credit default risk calculated by KMV model and weighted average method. The results are shown in Tab.2 in the appendix.

2.4 Determination of Financial System Risk Degree in China---Fuzzy Comprehensive Evaluation Method and Maximum Entropy Method

First, build a hierarchy fuzzy subset, determine membership, $\left(R \mid u_{i}\right)$, which things to the hierarchy fuzzy subset from single factor, and fuzzy relationship matrix can be obtained. The specific set of membership function table should refer to former literature, which is shown in Table 3 in the appendix.

Through membership function, we can obtain membership degree of each vintage variable. After that, based on the maximum entropy method to determine the weight of these variables, and obtain the stability of China's financial system from 2007 to 2013 data. The specific steps of Maximum Entropy Method are as follows:

(1) Select $\mathrm{n}$ years and $\mathrm{m}$ indicators. This paper selected 12 variables of Chinese financial system stability in 
2007-2013, and $x_{i j}$ is the first $j$ variable value of the first $i$ year. $(i=1,2, \ldots n ; j=1,2, \ldots m)$

(2) Standardize 12 financial indicators: make heterogeneous index into homogeneous index. This paper used maximum standardization method, in which $\operatorname{maxx}_{i j}$ are respectively 10 financial variable highest scores:

$$
X_{i j}=x_{i j} / \max _{i} x_{i j}
$$

(3) Calculate the proportion of the first $j$ variable value the first $i$ year to financial variables:

$$
P_{i j}=X_{i j} / \sum_{i=1}^{n} X_{i j} \quad(j=1,2, \cdots m)
$$

(4) Calculate the entropy value of the first $j$ financial variable:

$$
e_{j}=-k \sum_{i=1}^{n} P_{i j} \log \left(P_{i j}\right)
$$

Where $K$ is a constant greater than zero and is associated with sample $n$. Generally we assume $k=1 / \ln n$.

(5) Calculate diversity factor of the first $\boldsymbol{j}$ financial variable. For the first $\boldsymbol{j}$ financial variable, the greater the difference of index, the bigger the index's weight is and the smaller the entropy value is, we define diversity factor as:

$$
g_{j}=\left(1-e_{j}\right) /\left(m-E_{e}\right)
$$

where $_{E_{e}}=\sum_{j=1}^{m} g_{j}, 0 \leq g_{i} \leq 1, \sum_{j=1}^{m} g_{j}=1$.

(6) Solve comprehensive weights for each indicator:

$$
W_{j}=g_{j} / \sum_{j=1}^{m} g_{j}, j=1,2 \cdots m
$$

(7) Calculate integrated circumstance of the financial system stability:

$$
S_{i}=\sum_{j=1}^{m} W_{j} P_{i j}(i=1,2, \cdots n)
$$

We can get risk circumstance of final financial system by MATLAB, which can be shown in Tab.4 in the appendix.

\section{The Study of Relationship between China's Financial System Stability and Scale of the Shadow Banking}

After obtaining data of the China's financial system stability and scale of the shadow banking, we can get their relationship by regression. But traditional OLS regression can only reflect the static relationship between variables, cannot reflect the impact of dynamic effect, even cannot reflect the dynamic relationship between variables. Therefore, this paper chose Vector Auto-Regressive (VAR) model, which can reflect dynamic relationship between variables and dynamic impact, to study the impact of the shadow banking scale on financial system stability. VAR (r) model can be expressed as follow:

$$
Y_{t}=\left(\phi_{1} L+\cdots+\phi_{r} L^{r}\right) Y_{t}+B X+\varepsilon_{t}
$$

Where $\mathrm{L}$ is lag operator, $\mathrm{Y}_{t}$ is $\mathrm{K}$ dimensions endogenous variable, $\mathrm{X}$ is exogenous variable, $\mathrm{r}$ is lag order number, $\phi_{1} \ldots \phi_{r}$ is coefficient matrix of $k \times k$ dimension and $\varepsilon_{t}$ is error vector in $\mathrm{K}$ dimensions.

Change VAR (r) model in the form of MA, we can get,

$$
Y_{t}=\left(I_{k}-\Phi_{1} L-\cdots-\Phi_{p} L^{p}\right)^{-1} \varepsilon_{t}=\left(I_{k}+A_{1} L+A_{2} L^{2}+\cdots\right) \varepsilon_{t}
$$

The impulse response function of this equation is,

$$
I R F_{q}=\partial y_{t+q} / \partial \varepsilon_{t}^{\prime}
$$

The cumulative impulse response function is

$$
A I R F_{q}=\sum_{q=0}^{\infty} I R F_{i j}^{(q)}
$$

Impulse response function can reflect the effect of impact changing on system random error to the VAR system, 
and we can also see change path of the impact effect with changing of time through it, so it is well suited to analyze the robustness of the VAR system. Therefore, we also apply impulse response function to reflect long-term response path of shadow banking scale to financial system stability. Due to macro variable statistical interval is long, dependent and independent variables calculated in this paper are both based on a year, and they can reflect dynamic change of financial system better if calculated on a quater. Therefore, the first step is the tranquilization interpolation processing of variables, and we applied the Spline interpolation method, whose specific formula is as follow:

$$
S(x)=\frac{1}{6 h_{i}}\left[\left(x_{i}-x\right)^{3} M_{i-1}+\left(x-x_{i-1}\right)^{3} M_{i}\right]+\left(y_{i-1}-\frac{h_{i}^{2}}{6} M_{i-1}\right) \frac{x_{i}-x}{h_{i}}+\left(y_{i}-\frac{h_{i}^{2}}{6} M_{i}\right) \frac{x-x_{i-1}}{h_{i}}
$$

We applied logarithmic difference interpolation after data processing in order to get stable time series data LDX (relative size of the shadow banking) and LDY (financial system risk degrees). Make ADF unit root test to LDX and LDY, and test results are shown in Table 5 in the appendix.

According to results of unit root test, LDX and LDY we selected are smooth, so we can refuse original hypothesis that unit root exists fewer than 5\% significant relationship. Due to the smooth original data, there is no need cointegration testing, so we can establish VAR equation directly, and make impulse response analysis and variance decomposition.

Then we determine order number according to Lag Order Criteria of VAR, and according to the rule of LR, FPE and SIC, we can determine the optimal Lag Order number as 2, then make the granger causality test to test their causality. The results are shown in Table 6.

According to results in Tab.6, LDX and LDY have rejected null hypothesis in test, which are granger causality each other. This laid the groundwork for VAR model. The parameters of VAR model are shown in Table 7.

According to the result in Table 7, AR regression equation is significant overall, namely $\mathrm{F}$ coefficient of equation is rather big. Most $t$ statistics of coefficients are significant, meaning that regression of VAR is effective.

\section{Impulse Response Analysis}

After building VAR model, we analyzed impact effect of LDX to LDY, which is shown in Figure 2.

Response to Cholesky One S.D. Innovations
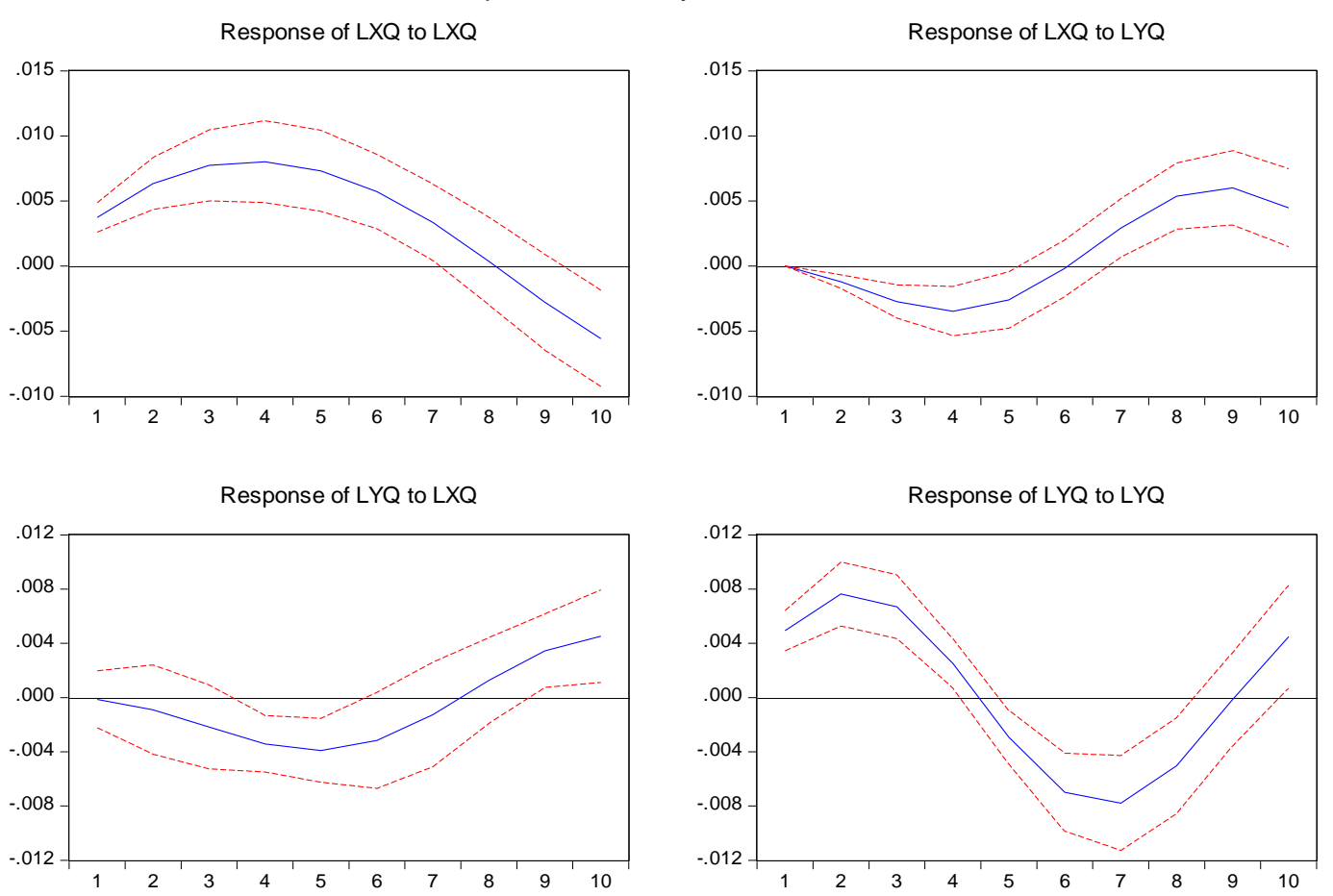

Figure 2. Figure of VAR impulse response function 
As can be seen from the results, if exert a positive impact on LXQ, shock response function value of LYQ in hysteretic 8 period ( 2 years) is negative, which suggests that in short term, incensement of the shadow banking scale reduces the risk degree of financial system. But as time goes on, shock response function value of LYQ increases gradually and eventually turns positive. Due to occurrence of shadow banking, pressure of capital flow in short term get eased, decrease of financial markets default rates will reduce risk of the financial system, while the negative effect of shadow banking to the financial system starting express around two years later, and in the financial market, the shadow banking capital chain began to fracture, underground financial institutions and private lenders began to run, at the same time, shadow banking's risk began to affect the whole society, so the risk of financial system stability is increasing. Therefore, controlling the absolute scale of shadow banking and loan quality is still an important thing to maintain China's financial system stability.

\section{Conclusion}

The impact of shadow banking scale to the financial system stability is one of the focuses of financial circles in recent years. At first, we estimated relative scale of the shadow banking system, and then we determined financial system stability through KMV model, fuzzy comprehensive evaluation method and maximum entropy method, and finally got the relationship between shadow banking scale and financial system stability by constructing a VAR model, and analyzed their impulse response function. We can find through empirical research: (1) The risk of security industry follow the up-after-first-down basic rule, and the risks of different industries and different individual stocks diversifies obviously; (2) In recent years, the risk degree of financial system basically presents a downward trend, but presents a slightly upward trend in the past two years; (3) Shadow banking scale has lag effect on financial system stability, namely incensement of the shadow banking scale will reduce the risk of financial system at the beginning, but in the lag 2 years it will increase the risk. This shows that only relying on the increase of shadow banking scale to reduce the risk of financial system is a dangerous act. The risk of financial system may be controlled in the short term, but in the long run, the risk will break out at some point, and its destructive power also increased greatly. Therefore, control the shadow banking scale appropriately, and reduce the risk of the financial system gradually are still things we should pay attention to in the current financial institutions.

\section{Acknowledgements}

The authors acknowledge the financial support of this research by the Enterprise Investment Project in Guangdong Province (No.2015-440402-65-03-010049).

\section{References}

Baily, M. N., Douglas, W. E., \& Robert, E. L. (2008). The Great Credit Squeeze: How it Happened, How to Prevent Another. Brookings Institution Discussion Paper, May, 1-163.

Bell, \& Keller. (200). Insurance and Stability: The Reform of Insurance Regulation. Zurich Financial Services Group.

Bengtsson, E. (2013). Shadow banking and financial stability: European money market funds in the global financial crisis. Journal of International Money and Finance, 32, 579-594. http://dx.doi.org/10.2139/ssrn.1772746

Calmes, \& Theoret. (2011). The rise of shadow banking and the hidden benefit of diversification. RePAd Working Paper Series, No UQO-DSA-wp042011.

Demirguc-Kunt, A., \& Detragiache. (1999). Financial Liberalization and Financial Fragility. Staff Papers, 45(1). IMF. http://dx.doi.org/10.1596/1813-9450-1917

Dongmin, L. (2013). Discussing from the definition of shadow banking in China. Discussion in Research Center of the International Financial (RCIF).

Feng, L. (2008). Credit risk measurement study of listed companies based on KMV model. Hunan University.

Gorton, \& Metrick. (2010). Haircuts. Forthcoming in Federal Reserve Bank of St. Louis Review.

Gorton, G. B., \& Metrick, A. (2009). Haircuts. National Bureau of Economic Research. http://dx.doi.org/10.3386/w15273

Gorton, G., \& Metrick, A. (2012). Securitized banking and the run on repo. Journal of Financial Economics, 104(3), 425-451. http://dx.doi.org/10.1016/j.jfineco.2011.03.016

Guohui, C. (2011). Application study of KMV model in commercial bank risk management. Central University of Finance and Economics. 
IMF (International Monetary Fund). (2010). Golabl Financial Stability Report 2009.

Irving, F. (1933). The Great Deflation Theory of Great Depressions. Econometrics, Jan., 335-337.

Jinru, Z. (2012). Credit risk management study in China's commercial bank based on KMV model. East China Normal University.

Lisheng, X. (2013). Report I of China's shadow banking system development research.

McCulley, P. (2007). Teton reflections. PIMCO Global Central Bank Focus.

Ming, Z. (2012). Wary systematic risk of China's banking. Discussion in Research Center of the International Financial (RCIF).

Ming, Z. (2012). Will there be a crisis of China's shadow banking system? Discussion in Research Center of the International Financial (RCIF).

Ming, Z. (2013). Shadow banking's next step. Discussion in Research Center of the International Financial (RCIF).

Minsky, H. (1982). The Financial Fragility Hypothesis: Capitalist Process and the Behavior of the Economy in Financial Crises (pp. 32-58). Cambridge University Press.

Mishkin, F. S. (2008). Risk, Management, and Financial Disruptions. speech delivered at the Federal Reserve Bank of New York.

Papadimitriou, D. B., Wray, L. R., \& Nersisyan, Y. (2010). Endgame for the euro? Without major restructuring, the eurozone is doomed. Public policy brief//Jerome Levy Economics Institute of Bard College.

Sichong, C. (2013). Report II of China's shadow banking system development research.

Wei, J. (2013). An empirical study on the effect of shadow banking on Chinese commercial banking system stability (pp. 1-58).

Yalan, W. (2013). An empirical study on the effect of China's shadow banking on the financial system stability (pp. 1-42).

Yin, L. (2010). Industry credit assessment based on KMV model. Beijing Jiaotong University.

Yue, L. (2015). Analysis of the impact of the shadow banking to the financial system. Financial and Economic, $20,47-48$.

Zhong, H. (2008). Application study based on the credit risk measurement model theories of commercial bank-An empirical study of KMV model of empirical companies. Nanjing University of Science and Technology.

\section{Appendix}

Table 1. Measurement of Shadow Banking scale

\begin{tabular}{lccccccc}
\hline & 2007 & 2008 & 2009 & 2010 & 2011 & 2012 & 2013 \\
\hline Pawnbrokers scale & 279 & 235 & 576 & 584 & 779.8 & 994.2 & 1217 \\
Internet financial scale & 976 & 2356 & 5551.5 & 10871.7 & 21694.2 & 38640.6 & 64828.3 \\
Private lending scale & 1.9 & 2.1 & 2.1 & 3.2 & 4.47 & 4.8 & 5.28 \\
Trust scale & 0.95 & 1.22 & 2.02 & 3.04 & 4.81 & 7.47 & 10.91 \\
Bank financing scale & 0.82 & 3.7 & 4.75 & 7.05 & 16.49 & 24.71 & 56.43 \\
The total amount of the shadow banking & $\mathbf{1 2 5 8 . 6 7}$ & $\mathbf{2 5 9 8 . 0 2}$ & $\mathbf{6 1 3 6 . 3 7}$ & $\mathbf{1 1 4 6 8 . 9 9}$ & $\mathbf{2 2 4 9 9 . 7 7}$ & $\mathbf{3 9 6 7 1 . 7 8}$ & $\mathbf{6 6 1 1 7 . 9 2}$ \\
Total social financing & 5275.6 & $\mathbf{6 9 8 0 . 4}$ & 13910.5 & 14019.1 & 12828.6 & 15763.08 & 17316.83 \\
relative scale of Shadow Banking & $\mathbf{0 . 2 3 8 6}$ & $\mathbf{0 . 3 7 2 2}$ & $\mathbf{0 . 4 4 1 1}$ & $\mathbf{0 . 8 1 8 1}$ & $\mathbf{1 . 7 5 3 9}$ & $\mathbf{2 . 5 1 6 8}$ & $\mathbf{3 . 8 1 8 1}$ \\
\hline
\end{tabular}

* The relative scale of the shadow banking refers to total amount of the shadow banking divided by total social financing.

Table 2. Integrated credit risk calculated by KMV model

\begin{tabular}{llllllll}
\hline & 2007 & 2008 & 2009 & 2010 & 2011 & 2012 & 2013 \\
\hline Integrated credit risk & $\mathbf{1 . 5 2}$ & $\mathbf{1 . 4 0 4}$ & $\mathbf{2 . 0 1 1}$ & $\mathbf{2 . 7 5 4}$ & $\mathbf{2 . 9 6 6}$ & $\mathbf{3 . 5 4}$ & $\mathbf{2 . 5 9 8}$ \\
\hline
\end{tabular}


Table 3. Membership function table of variables in financial system

\begin{tabular}{|c|c|c|c|c|c|c|}
\hline & \multirow{2}{*}{\multicolumn{2}{|c|}{ Indicator system }} & \multicolumn{4}{|c|}{ Risk state } \\
\hline & & & Safe & Normal & Concerned & Risky \\
\hline & & Scores & 1 & 2 & 3 & 4 \\
\hline \multirow{8}{*}{$\begin{array}{l}\text { Systematic } \\
\text { risk }\end{array}$} & \multirow{4}{*}{$\begin{array}{c}\text { A } \\
\text { Economic } \\
\text { variables }\end{array}$} & A1 GDP growth rate $\%$ & {$[10,+\infty)$} & $(8,10]$ & $(6.5,8]$ & $(-\infty, 6.5]$ \\
\hline & & A2 inflation rate $\%$ & {$[0,4]$} & $(4,7]$ & $(7,10] \mathrm{U}(0,-2]$ & $(-\infty,-2] \cup(10,+\infty)$ \\
\hline & & $\begin{array}{l}\text { A3The growth rate of investment in } \\
\text { fixed assets } \%\end{array}$ & {$[15,17]$} & {$[14,15) \mathrm{U}(17,19]$} & {$[8,14) \mathrm{U}(19,22]$} & $(-\infty, 8) \mathrm{U}(22,+\infty)$ \\
\hline & & A4 Ratio of fiscal deficit to GDP & {$[0,0.1)$} & {$[0.1,0.2)$} & {$[0.2,0.3)$} & {$[0.3,+\infty)$} \\
\hline & \multirow{4}{*}{$\begin{array}{c}\text { B } \\
\text { Financial } \\
\text { variables }\end{array}$} & B1 M2 growth rate $\%$ & {$[5,15]$} & $(15,20]$ & $(0,5] \mathrm{U}(20,25]$ & $(-\infty, 0] \mathrm{U}(25,+\infty)$ \\
\hline & & B2 Household saving rate $\%$ & {$[9,11]$} & $(7,9] \mathrm{U}(11,14]$ & $(3,7] \mathrm{U}(14,20]$ & $(-\infty, 3] \cup(20,+\infty)$ \\
\hline & & B3 Financial credit growth rate $\%$ & {$[5,15]$} & $(15,20]$ & $(0,5] \mathrm{U}(20,25]$ & $(-\infty, 0] \mathrm{U}(25,+\infty)$ \\
\hline & & B4 One-year real deposit rate\% & {$[0,4]$} & {$[-4,0) \mathrm{U}(4,7]$} & {$[-8,-4) \mathrm{U}(7,10]$} & $(-\infty, 8) \mathrm{U}(10,+\infty)$ \\
\hline \multirow{4}{*}{$\begin{array}{l}\text { Market } \\
\text { risk }\end{array}$} & \multirow{3}{*}{$\begin{array}{c}\text { C } \\
\text { Bank system }\end{array}$} & C1 Bank capital adequacy ratio\% & {$[12,100)$} & $(10,12]$ & $(10,8]$ & $(0,8]$ \\
\hline & & C2 Bank non-performing loan rate $\%$ & $(0,0.01]$ & $(0.01,0.03]$ & $(0.03,0.05]$ & {$[0.05,+\infty)$} \\
\hline & & C3 Bank net profit margin rate $\%$ & {$[1.25,+\infty)$} & $(1.1,1.25]$ & $(1,1.1]$ & $(-\infty, 1]$ \\
\hline & Securities market & D1 Comprehensive credit risk degree & {$[3,+\infty)$} & $(2,3]$ & $(1,2]$ & $(0,1]$ \\
\hline
\end{tabular}

*12 indicators are selected according to former literatures.

Table 4. Risk value of China's financial system

\begin{tabular}{ccccccc}
\hline $\mathbf{2 0 0 7}$ & $\mathbf{2 0 0 8}$ & $\mathbf{2 0 0 9}$ & $\mathbf{2 0 1 0}$ & $\mathbf{2 0 1 1}$ & $\mathbf{2 0 1 2}$ & $\mathbf{2 0 1 3}$ \\
\hline 0.78779 & 0.71567 & 0.82607 & 0.6201 & 0.622 & 0.53644 & 0.5427 \\
\hline
\end{tabular}

Table 5. The results of ADF unit root test

\begin{tabular}{cccc}
\hline & ADF value & $5 \%$ critical value & Smooth or not \\
\hline LDX & -3.37362 & -3.04039 & Smooth \\
LDY & -9.46522 & -3.00486 & Smooth \\
\hline
\end{tabular}

Table 6. The results of granger causality test

\begin{tabular}{cccc}
\hline Null Hypothesis: & Obs & F-Statistic & Prob. \\
\hline LYQ does not Granger Cause LXQ & 22 & 21.375 & $2.00 \mathrm{E}-05$ \\
LXQ does not Granger Cause LYQ & 22 & 12.2029 & 0.0005 \\
\hline
\end{tabular}

Table 7. Regression parameter of high frequency volatility VAR

\begin{tabular}{cccccc}
\hline & LXQ & LYQ & & LXQ & LYQ \\
\hline LXQ(-1) & 1.688247 & -0.185249 & LYQ(-1) & -0.242623 & 1.54832 \\
& -0.04226 & -0.05578 & & -0.03885 & -0.05127 \\
& {$\left[\mathbf{3 9 . 9 5 1 8 *}^{*}\right.$ LXQ(-2) } & {$[-3.32127 *]$} & & {$[-6.2458 *]$} & {$[\mathbf{3 0 . 1 9 7 3} *]$} \\
& -0.845996 & 0.065197 & LYQ(-2) & 0.230669 & -1.0852 \\
& -0.0378 & -0.04989 & & -0.04029 & -0.05319 \\
C & {$[-22.3826 *]$} & {$[1.30683]$} & & {$[\mathbf{5 . 7 2 4 6 2 *}]$} & {$[-\mathbf{- 2 0 . 4 0 4 0 *}]$} \\
& $1.92 \mathrm{E}-02$ & $4.89 \mathrm{E}-03$ & F-Stats & $\mathbf{1 2 3 3 . 0 6 6}$ & $\mathbf{3 3 6 . 8 8 7}$ \\
& $-2.07 \mathrm{E}-03$ & $-2.74 \mathrm{E}-03$ & S.E. & $\mathbf{0 . 0 0 3 7 3 8}$ & $\mathbf{4 . 9 3 E - 0 3}$ \\
& {$[\mathbf{9 . 2 5 2 5 1 *}]$} & {$[1.78609]$} & Log likelihood & 94.57943 & 88.47266 \\
\hline
\end{tabular}

* Line 1 of parameter stands for coefficient, line 2 is standard error and line 3 is t-value.

\section{Copyrights}

Copyright for this article is retained by the author(s), with first publication rights granted to the journal.

This is an open-access article distributed under the terms and conditions of the Creative Commons Attribution license (http://creativecommons.org/licenses/by/3.0/). 